\title{
Risk shifting in the context of 3D printing: an insurability perspective
}

\author{
Citation for published version (APA):
}

Faure, M., \& Li, S. (2020). Risk shifting in the context of 3D printing: an insurability perspective. Geneva Papers on Risk and Insurance - Issues and Practice, 45(3), 482-507. https://doi.org/10.1057/s41288-02000164-9

Document status and date:

Published: 01/07/2020

DOI:

10.1057/s41288-020-00164-9

Document Version:

Publisher's PDF, also known as Version of record

Document license:
Taverne

\section{Please check the document version of this publication:}

- A submitted manuscript is the version of the article upon submission and before peer-review. There can be important differences between the submitted version and the official published version of record.

People interested in the research are advised to contact the author for the final version of the publication, or visit the DOI to the publisher's website.

- The final author version and the galley proof are versions of the publication after peer review.

- The final published version features the final layout of the paper including the volume, issue and page numbers.

Link to publication

\footnotetext{
General rights rights.

- You may freely distribute the URL identifying the publication in the public portal. please follow below link for the End User Agreement:

www.umlib.nl/taverne-license

Take down policy

If you believe that this document breaches copyright please contact us at:

repository@maastrichtuniversity.nl

providing details and we will investigate your claim.
}

Copyright and moral rights for the publications made accessible in the public portal are retained by the authors and/or other copyright owners and it is a condition of accessing publications that users recognise and abide by the legal requirements associated with these

- Users may download and print one copy of any publication from the public portal for the purpose of private study or research.

- You may not further distribute the material or use it for any profit-making activity or commercial gain

If the publication is distributed under the terms of Article $25 \mathrm{fa}$ of the Dutch Copyright Act, indicated by the "Taverne" license above, 


\title{
Risk shifting in the context of 3D printing: an insurability perspective
}

\author{
Michael Faure ${ }^{1,2} \cdot$ Shu $\mathrm{Li}^{2}$
}

Received: 4 September 2019 / Accepted: 24 February 2020 / Published online: 11 April 2020

(c) The Geneva Association 2020

\begin{abstract}
The adoption of 3D printing poses considerable liability risk to digital designers and fabricators. Traditionally, liability insurance is considered a crucial way for parties to shift their risk. However, in the context of 3D printing, uninsurability may serve as an obstacle for risk shifting. The main interest of this article is twofold. On the one hand, it sketches the extent to which risk can be unforeseeable (and thus uninsurable) in the context of 3D printing when legal uncertainties and the existence of adverse selection and moral hazard are considered. On the other hand, by reviewing various instruments, it offers potential solutions for reducing the uninsurability problem. Specific emphasis is given to applying InsurTechs, especially blockchain technology, to improve insurability and to identify the problems that will constrain the promotion of InsurTech in the context of 3D printing.
\end{abstract}

Keywords 3D printing $\cdot$ Product liability $\cdot$ Liability insurance $\cdot$ Insurability $\cdot$ InsurTechs

\section{Shu Li}

li@law.eur.nl

Michael Faure

michael.faure@maastrichtuniversity.nl

1 Maastricht European Institute for Transnational Legal Research (METRO), Maastricht University, Bouillonstraat 3, 6211 LH Maastricht, The Netherlands

2 Rotterdam Institute of Law and Economics, Erasmus University Rotterdam, Burgemeester Oudlaan 50, 3062 PA Rotterdam, The Netherlands 


\section{Introduction}

With easier access to various innovative technologies, ordinary individuals are capable of engaging in many activities that in the past could only be accomplished by professionals. While this tendency promotes innovation and benefits the whole of society to a large extent, it generates risk as well. This paper focuses on 3D printing as an example to reflect this trend. It will show that new product risk may arise in the context of 3D printing. The legal interventions concerning product risk will not only have an impact on optimal deterrence but will also affect the demand for risk shifting. The goal of this article is not to analyse how legal instruments should be arranged to provide the parties involved with incentives towards optimal deterrence. ${ }^{1}$ Rather, the particular interest of this paper is to study the extent to which it could become more difficult to foresee the generated liability risks in the context of $3 \mathrm{D}$ printing, thus potentially affecting insurability and the extent to which different instruments can remedy this problem.

The limits to insurability and corresponding remedies against uninsurability are not a new topic in the literature. Since the 1990s, corresponding with disruptive social and technological transformations, not only have traditional risks changed tremendously, but new risks have also been generated. Against this background, insurers are in practice confronted with huge uncertainties and they hesitate to offer insurance coverage. Topics ranging from the factors that might have an impact on insurability ${ }^{2}$ to the potential solutions to overcome uninsurability ${ }^{3}$ have been discussed in the literature, specifically the limits to the uinsurability of the liability risk. ${ }^{4}$ However, while these discussions offer theoretical insight into this topic, they are still restricted in the conventional context. As new technologies and ensuing social transformations keep disrupting the world, it is necessary to go back to check this old topic in the new era. ${ }^{5}$

This article will proceed as follows. The next section will briefly introduce what 3D printing is from a technological perspective and explain what characteristics distinguish $3 \mathrm{D}$ printing from traditional mass production. In the third section we shift the focus to examining the risk as well as the corresponding liabilities that are created in the context of 3D printing. We show that new entrants like digital designers and individuals who take the role of producers are likely to run the risk of bearing liability. As a result, given risk aversion, they tend to seek methods for shifting such liability risk. This explains that insurance will be demanded as a method of risk shifting in the context of 3D printing. On this basis, in the fourth section we turn to

\footnotetext{
1 That has been extensively addressed in the work of Shavell (1980, 1987) and Landes and Posner (1987).

${ }^{2}$ For the original arguments on this topic, see Arrow (1968) and Shavell (1979). For an overview of the factors resulting in uninsurability, see Faure and Hartlief (1998), Mehl (1998) and Kousky and Cooke (2012).

${ }^{3}$ For an overview of the traditional methods of reducing uninsurability problems, see Karten (1997) and Faure (2004).

4 Baker (2004).

5 Literature has already paid attention to the issue of insurability. See Eling and Lehmann (2018).
} 
the core issue, i.e. that insurability might be endangered in the context of 3D printing. We explain that insurers might hesitate to provide liability insurance unless the legal uncertainties and adverse selection as well as moral hazard can be reduced. In the fifth section we focus on the potential solutions to the uninsurability problems in the context of 3D printing and, more specifically, we examine the extent to which new methods, such as platform governance and InsurTechs can provide appropriate remedies. The final section concludes.

\section{An overview of 3D printing technology and the ensuing disruption}

$3 \mathrm{D}$ printing refers to a manufacturing process through which a physical object can be reproduced layer by layer under the instruction of a digital design (the so-called CAD file). ${ }^{6}$ Technologically, the application of 3D printing makes it possible to transform intangibles and tangibles within a single process. The past few years have witnessed incredible applications of 3D printing technology. Objects produced by $3 \mathrm{D}$ printing can be found in numerous sectors, ranging from automobile components to healthcare, from highly demanding aerospace engineering to gadgets for household use. ${ }^{7}$ Several features of 3D printing ensure that new value is created in its application, further distinguishing 3D printing from traditional production. ${ }^{8}$

Unlike the traditional production process in which fabrication adds the most value, $3 \mathrm{D}$ printing promotes added value to a large extent in the process of digital modelling. From a technical perspective, the party who works out the CAD file plays a more important role than the one who fabricates it into a product, since the former directly determines the function of the object while the fabricator simply follows the instructions of the CAD file and carries out ancillary work. Therefore, the first disruption caused by $3 \mathrm{D}$ printing lies in the increasing importance of digital designing. As a consequence, a non-embedded digital good fundamentally determines the quality of the product, thus blurring the product/service dichotomy. ${ }^{9}$

In addition, 3D printing adds value to production activities not only by lowering the threshold of production but also by capturing the small demands on the "long tail". ${ }^{10}$ Traditionally, production is organised under scale economies, which means that a producer will hold a competitive advantage on the value chain provided that $\mathrm{s} /$ he is able to produce an identical product at a lower cost. ${ }^{11}$ A variety of methods can be employed by producers to form a scale. In other words, the producers that are unable to purchase advanced machines and to maintain a stable relationship with other providers are most likely to be excluded from the value chain. The small marginal cost of producing an identical product on a large scale motivates producers

\footnotetext{
6 Gibson et al. (2015)

7 For detailed applications of 3D printing technology, see Redwood et al. (2017, pp. 226-285).

8 Staed (2017).

9 Howells et al. (2017).

10 Anderson (2007).

11 Berman (2012).
} 
to produce a few kinds of the most demanded products instead of taking the risk to produce a variety of products. While this strategy appears to safeguard profits and to ensure a competitive market position for producers, it is achieved at the expense of omitting large quantities of demands on the "long tail". ${ }^{12}$ This situation is significantly changed by the adoption of 3D printing. As the product can be customised via digital modelling, the marginal cost of manufacturing and obtaining a new product is much lower than in mass production. ${ }^{13}$ Therefore, instead of creating value on the basis of scale economies, value is added in the context of 3D printing by satisfying specific demands from consumers. As a result, production is no longer the privilege of mass producers that are able to take advantage of scale. In contrast, non-professionals with average expertise can substantially contribute to production. ${ }^{14}$

Three types of business models are generally distinguished to capture the value created by 3D printing. The first one (Model A) is established in order to the match the supply of the CAD file with the demands for it. Several methods can be further categorised within this process: (1) obtaining a CAD file through an open-source community where a CAD file can be remixed several times before it is downloaded by a person (Model A.1) ${ }^{15}$; (2) purchasing a CAD file from an online marketplace (Model A.2) ${ }^{16}$; and (3) collaborating with a digital designer to customise a CAD file that best fits one's preference (Model A.3). ${ }^{17}$ Business models are also established around fabricating activities (Model B), the purpose of which is to help a person who has a CAD file to print out the final product. The business model relating to fabrication can be further divided into three approaches: (1) a consumer can go directly to a fabricator to have the CAD file printed out (Model B.1) ${ }^{18} ;(2)$ an online platform can serve as a marketplace where consumers can identify various fabricators around the world (Model B.2) ${ }^{19}$; and (3) an online platform can function as an intermediary to choose an appropriate fabricator for a consumer (Model B.3). ${ }^{20}$ Third, a party can set up a "one-stop" business model (Model C) to capture the value in digital designing as well as in fabrication. ${ }^{21}$

To conclude this part, compared to traditional manufacturing, applying 3D printing to production gives rise to two essential types of disruption. On the one hand, digital modelling plays an even more critical role than physical fabricating. On the

\footnotetext{
12 In this sense, while the popular items which are in high demand can be satisfied by the production dominated by scale economies, the demands outside the mainstream goods in total also represent a huge market. However, such demands do not fit in mass production. The value on the long tail can be captured only if specific ways of production are able to satisfy this huge group of people. See Anderson (2007).

13 With mass production, producing a different variety of products means that a producer has to develop new moulds, purchase new machines and invest in adjusting the current organisational structure. Such expense could be huge. See Khorram et al. (2017).

14 Rayna and Striukova (2014) and Bogers et al. (2016).

15 The typical case is Thingiverse. For more information, see: https://www.thingiverse.com/

16 The typical case is Pinshape. For more information, see: https://pinshape.com/.

17 The typical case is Shapeways. For more information, see: https://www.shapeways.com/.

18 The typical case is Sculpteo. For more information, see: https://www.sculpteo.com/en/.

19 The typical case is Treatstock. For more information, see: https://www.treatstock.com/.

20 The typical case is 3D Hubs. For more information, see: https://www.3dhubs.com/.

21 The typical case is Carbon. For more information, see: https://www.carbon3d.com/.
} 
other hand, various parties (especially SMEs and individuals) are able to find a place in the value chain and substantially engage in related activities.

\section{Product risk, liability risk and the demand for liability insurance}

While 3D printing is substantively taking on a role of production parallel to traditional mass production, the methods to reduce and shift the risk in this scenario appear to be falling behind. ${ }^{22}$ In this section, the extent to which specific liability risks are created and insurance is accordingly demanded will be discussed.

\section{Product risk in 3D printing: going beyond mass production}

Since the method of mass production was introduced, the world has witnessed tough battles on how to reduce the product risks it has generated. After more than a century's exploration, it is safe to conclude that a variety of instruments were developed to deal with the potential product risks. ${ }^{23}$ As production activities embrace more complex methods and supply chains, the need to monitor the activities of producers increases.

In theory, legal interventions are unnecessary on condition that transaction cost is low and users can perfectly understand the risk of a product. ${ }^{24}$ Where this is the case, the consumer is able to observe and bargain with the producer before making a decision. As the consumer also has the ability to acquire sufficient information about the product, s/he will fully understand not only the level of care taken by the producer but also the expected scale of damage. As a result, the consumer has knowledge of the full price of the product and further will compare it with its utility. ${ }^{25}$ In this ideal situation, even though interventions are not provided, an efficient outcome can be reached. ${ }^{26}$

However, this ideal scenario can hardly be observed in practice. On the one hand, prohibitive transaction cost might exist between the producer and the injured party. ${ }^{27}$ When the injured party is a third party, there is no chance of reaching an ex ante agreement on risk allocation with the producer. ${ }^{28}$ Transaction cost also increases in a scenario where a consumer and a producer cannot directly bargain with each other

\footnotetext{
22 This phenomenon is not restricted by the emergence of 3D printing. For example, the recently adopted Directive on Insurance Distribution (2016/97/EU) does not offer provisions on digital distribution.

23 Such instruments include the economies of scale per se, the contractual relationship curved by the linear supply chain, the expanding scope of liability regimes and the ubiquitous regulations and standards. See, for example, Epstein (1980) and Geistfeld (2009). Many more diverse measures are also on the way as the new regulatory techniques are applied in practice.

24 Coase (1960).

25 The full price perceived by the consumer consists of the cost of precaution as well as the expected harm. See Geistfeld (1988) and Daughety and Reinganum (2013).

26 McKean (1970), Oi (1973) and Daughety and Reinganum (2013).

27 Goldberg (1974), Schäfer and Müller-Langer (2009) and Arlen (2010).

28 Shavell (1987).
} 
due to the transformation of the supply chain post industrial revolution. ${ }^{29}$ On the other hand, consumers might struggle to obtain complete information needed for the evaluation of the full price of the product. ${ }^{30}$ This can be observed especially when the user has limited knowledge of the product and no direct physical access to check the conditions of the product. ${ }^{31}$ The fact that consumers have substantial difficulties in precisely assessing the full price of a product incentivises the producer to behave inappropriately, as a result of which optimal deterrence is distorted. ${ }^{32}$

Traditionally, in a contractual relationship, product warranties are employed to counter the aforementioned problems. ${ }^{33}$ However, efficiency can be distorted under specific conditions, especially when third parties incur damage or injured parties cannot precisely determine the value of warranties. ${ }^{34}$ Also, risk can be unfairly allocated between the seller and consumer due to the existence of defensive exemptions and insolvency problems. All these factors lead consumers to misunderstand the full price of the product, which calls for additional instruments. ${ }^{35}$ The deficiencies of contracting over liability persist in the context of 3D printing. On the one hand, in several of the above-mentioned business models a contractual relationship is not observed, since relevant parties are strangers to each other (e.g. Model A.1). On the other hand, despite mandatory warranties required by laws to some extent, ${ }^{36}$ multiple concerns prevent sellers from voluntarily offering warranties in various business models (e.g. Model A.2, Model A.3 and Model B.2) ${ }^{37}$ More importantly, less credible signals of the product risk are not even accessed by consumers before contracting with the sellers. ${ }^{38}$

The failure of contracting over product risk indicates that achieving optimal deterrence by way of contract law is insufficient. Without the constraint of the contractual privity and with the function of revealing information, a tort liability regime is regarded as a promising mechanism to remedy the remaining problems. ${ }^{39}$

\footnotetext{
29 In this sense, in the aftermath of the industrial revolution, as various intermediaries such as suppliers and retailers engage in the supply chain, the direct contractual relationship between the producer and the consumer is replaced by a chain of contracts. As a result, a consumer can only reach an agreement with the seller. A similar observation can also be found in the insurance industry where insurance agents and brokers are emerging to connect insured parties with insurers.

30 The full price of a product includes not only the production cost per unit but also its accident costs. Spence (1977).

31 Dean (2018).

32 Daughety and Reinganum (2013).

33 See Grossman (1981) and Parisi (2004).

34 Gerner and Bryant (1981).

35 Goldberg (1974).

36 For instance, the Directive on Digital Contract (2019/770/EU) and the Directive on Consumer Rights (2011/83/EU) require some compliance on behaviour and information disclosure, respectively.

37 Sellers are less motivated to provide voluntarily warranties where sellers are risk-averse, where technical uncertainties exist, where their customised conception is less alternative and where adverse selection and moral hazard problems arise with consumers.

38 Such signals are regulatory compliance, standards, authoritative accreditation, reputation, etc. See Heine and Li (2019).

39 Hylton (2012).
} 


\section{Product liability in 3D printing}

In general, two kinds of rules (i.e. fault-based liability and strict liability) are distinguished. The performance of the tort liability regime in terms of deterring a product risk has been thoroughly studied by the law and economics literature over the past decades. ${ }^{40}$ In general, while both liability rules can incentivise the parties to adopt optimal care levels, their effects are totally different when it comes to activity levels. ${ }^{41}$ Only a strict liability-based regime can motivate producers to optimise their activity level. ${ }^{42}$ Applying strict liability also has a significant implication regarding the information offered to the injured parties, since the market price perceived by them will also include the precaution taken by the producer and the expected damage caused by the product risk. ${ }^{43}$ As such, users will understand the risk of the specific product via the strict liability regime, which further helps them to make correct decisions. For a long time, the fault-based rule applied to the damage caused in the use of products. This landscape, however, has greatly shifted since the 1960s, and in 1985, by virtue of the enactment of the European Product Liability Directive ${ }^{44}$ (the "EPLD") strict liability was finally established across the EU.

Strict liability applies to the producer that manufactured the defective product. ${ }^{45}$ As digital technologies encroach more and more upon the sector of production, divergences are generated in the light of understanding particular elements among different Member States. In this regard, disputes arise when it comes to the explanation of particular elements within the EPLD. Can a digital good be considered a "product"? Is an individual producer considered a "producer" just as in traditional mass production? Can a digital good that is offered in service be considered a "product"? From a positive legal perspective, damage caused by digital goods in most of the Member States can still only be tackled through the contractual relationship. However, the EU is witnessing a trend whereby Member States are increasingly expanding the application of strict liability towards such goods. ${ }^{46}$

\footnotetext{
40 See in general Shavell (1980), Shavell (1987) and Landes and Posner (1987).

${ }^{41}$ Shavell (1980) and Shavell (1987, pp. 21-31).

42 Diamond (1974).

${ }^{43}$ Spence (1977).

${ }^{44}$ COUNCIL DIRECTIVE of 25 July 1985 on the approximation of the laws, regulations and administrative provisions of the Member States concerning liability for defective products (85/374/EEC), No L $210 / 29$.

45 According to Article 3 of the EPLD, the scope of 'producer' includes "the manufacturer of a finished product, the producer of any raw material or the manufacturer of a component part and any person who, by putting his name, trade mark or other distinguishing feature on the product presents himself as its producer." Articles 4 and 5 further extend the meaning of 'producer' to the importer that brought the product into the EU and the supplier, provided that the aforementioned producer cannot be identified by the consumer.

${ }^{46}$ Howells et al. (2017) and Machnikowski (2016). Some Member States are expanding the application of strict liability toward digital goods in their domestic laws or cases. For example, $\$ 1063$ of the Law of Obligations Act in Estonia states that "[a]ny movable is deemed to be a product, ... and computer software are also deemed to be movables." Likewise, cases in Germany also imply that online software, which is not embedded into the material medium is interpreted as the product under German Product Liability Act. See Ulrich (2016).
} 
According to the theory of law and economics, whether this expansion can improve social welfare is primarily determined by whether it can provide the involved parties with the optimal incentive to reduce risk, which is determined by a variety of factors. ${ }^{47}$ While achieving optimal deterrence serves the goal in maximising social welfare, risk shifting is also of great importance. Social welfare will be diminished if a risk-averse party ultimately bears the risk. ${ }^{48}$ Therefore, the main interest of this article is not to examine whether strict liability or negligence is more desirable. Instead, we explore how to help the risk-averse parties (e.g. digital designers and individual fabricators) who are allocated liability risk in the context of 3D printing to shift their risks.

\section{The demand for risk shifting in 3D printing}

According to law and economic theories, the essential factor that drives a party to demand a shift of risk lies in their attitude to risk. ${ }^{49}$ In this sense, if a party pays more attention to the absolute size of the possible losses rather than to the expected ones (probability multiplied by losses), they are regarded as risk-averse rather than risk-neutral. ${ }^{50}$ Several factors determine the risk attitude as well as the corresponding demand for risk shifting.

First, the institutional designs have direct influence on whether a specific party has a demand to shift a risk. If a party does not bear any risk within specific liability rules, then even if the party is risk-averse in nature, there is no need to shift the risk. ${ }^{51}$ However, if a party has to bear the residual risk under a specific liability rule, then risk-averse individuals will turn to possible instruments to shift risks. To explain this point, if strict liability is imposed, then it is the injurer that eventually bears the risk, as a result of which s/he will be motivated to shift the risk. ${ }^{52}$ In comparison, if the injurer is subject to a fault-based rule, then the injured party bears the residual risk. ${ }^{53}$ As a result, the risk-averse injured party will seek to shift the risk. ${ }^{54}$ Note that the injurer can also bear risks under the negligence rule if the court wrongly defines him/her as at fault when s/he has already taken due care. In this particular case, risk-averse injurers also desire to shift the risk. ${ }^{55}$

\footnotetext{
47 Such factors range from care level, activity level, information, court errors and uncertainties, insurance, judgement-proof problem to administrative costs. See in general Shavell (1987).

48 Calabresi (1970) and Shavell (1987).

49 Shavell (1982, 1987).

50 On facing the choice between a small but certain loss and a large but uncertain loss, risk-averse parties would like to choose the former. For risk-averse parties, as the marginal utility declines rather than stays constant, large losses weigh more heavily on them. See Wagner (2009).

51 Shavell (1987).

52 That is, the risk-averse injurers will be incentivised to purchase liability insurance.

53 The fact that strict liability and negligence lead to a demand for different types of insurance (accident insurance by victims under negligence versus liability insurance for injurers under strict liability) has been worked out by Shavell (1982).

54 That is, the risk-averse victims will be incentivised to purchase accident insurance.

55 Shavell (1987) and Geistfeld (2010).
} 
What is more, the incentive to shift a risk also depends on the wealth of the risk bearer. In this sense, it is safe to say that a wealthy party might be less risk-averse because a wealthy party has the capacity to deal with the risk. However, it is reasonable to assume that a less wealthy party is more risk-averse and is willing to spend a small portion of money ex ante to avoid a potentially large loss.

Moreover, the magnitude of damage also has an impact on the risk attitude. For instance, provided that the potential damage is huge, then even if the risk bearer is wealthy, s/he might be cautious and decide to protect assets by shifting the risk. In comparison, in cases where the potential risk is minor, then even if the risk bearer is less wealthy, s/he might behave as risk-neutral.

Taking the above-mentioned factors into account in a 3D printing scenario, there are various reasons why risk-averse parties have an incentive to shift risks.

First, the scope of the liability regime plays an important role. As analysed earlier in this section, actors such as CAD file makers and fabricators, being ordinary individuals or small entities, may be subject to strict liability in the context of $3 \mathrm{D}$ printing. ${ }^{56}$ In this case, such actors are forced to bear the liability risk related to their 3D printing activity, and if they are risk-averse they will be incentivised to purchase liability insurance. In addition, even in a Member State that has not extended strict liability to CAD file makers and individual producers, there is still a demand for shifting risk via liability insurance, since courts may wrongly find them negligent even if they have taken due care.

Besides the potential liability risk, wealth constraints might also play a role in terms of demanding liability insurance. Unlike mass producers that are organised in the form of corporations with limited liability and corporate assets to deal with the risk, individual producers can only take responsibility to the limit of their personal assets. $^{57}$ Therefore, it is reasonable to assume that individual producers might be less wealthy compared to traditional producers. Hence they might be more motivated to purchase liability insurance to deal with the liability risk.

Taking all these arguments into consideration, risk-shifting devices will be demanded by producers in the context of 3D printing. The next question is whether liability insurance is likely to be provided. In other words, we have to examine the insurability of the risk generated by the wide adoption of 3D printing, which will constitute the main discussion in the following section.

\section{Insurability in the context of 3D printing}

Basically, risk is insurable if it is predictable to the insurer. ${ }^{58}$ In other words, if an insurer can determine the probability of the accident as well as the magnitude of the damage, the risk can in principle be considered as insurable. ${ }^{59}$ However, insurers are wary of offering insurance when risks become unforeseeable. Literature on law,

\footnotetext{
56 Engstrom (2013), Berkowitz (2014) and Beck and Jacobson (2017).

57 Ackel (2018).

58 Faure and Hartlief (2003).

59 Such risks are categorised as "actuarial risks", referring to the risks that are experienced regularly and repeatedly. In addition, information on the assessment of such risks is also normally publicly available to the insurers, for example via statistics. See Skogh (1998).
} 
economics and insurance has determined several key factors that might deter insurers from providing insurance for a specific risk. ${ }^{60}$ In this section we will examine the potential factors that might affect the insurability in general, and we analyse them in the context of $3 \mathrm{D}$ printing.

\section{The unpredictable risks: legal uncertainties}

Legal certainty plays an important role when an insurer decides whether or not liability insurance should be provided. ${ }^{61}$ If an insurer is aware of the scope and possibility of liability during the insurance period, then the insurer can calculate the premium. However, legal uncertainties are ubiquitous when 3D printing is adopted for production. Due to the absence of explicit provisions, the definitions that are used to determine the application of liability are ambiguous. These legal uncertainties also lead judges to make errors in the application of liability rules.

\section{Uncertainties concerning what constitutes a product and who is a producer}

The legal uncertainties are related first to the ambiguity concerning the elements that are used to evaluate liability rules. In practice, divergence can be observed among Member States particularly concerning the question of what constitutes a product and who is a producer.

First, the meaning of a product is challenged from two aspects. On the one hand, it is not clear whether the non-embedded digital goods per se are a product or not. ${ }^{62}$ The EPLD does not explicitly interpret this issue. ${ }^{63}$ At the current stage, two different approaches can be identified at the level of Member States. One approach is that digital goods can be regarded as a product only if they are materialised in a tangible medium. According to this definition, non-embedded digital goods are thus not regarded as a product under the EPLD. ${ }^{64}$ The other direction consists of admitting that non-embedded digital goods are treated as a product, given that they play a substantial role in the resulting harm. This latter direction is not only followed in several Member States ${ }^{65}$ but is also welcomed in recent

\footnotetext{
${ }^{60}$ For the typical discussion in law and economics literature, see Faure (1995) and Geistfeld (2010). For the typical discussion in insurance literature, see Giarini (1995), Hamilton (1995) and Vermaat (1995).

61 Faure (1995).

62 A product is defined as non-embedded digital goods if it can exist without physically adhering to a tangible medium. Typical non-embedded digital goods are APPs and software.

63 This issue has been raised by the European Commission in the latest evaluation of the EPLD where a specific question is asked "whether apps and non-embedded software or the Internet of Things (IoT) based products are considered as products under the directive". See the European Commission (2018a).

64 This approach was predominant in many domestic laws for a long time. For example, German courts indicated that explaining software as being a product when it is stored on a material medium like a CD carrier is consistent with the purpose of the German Product Liability Act. See Magnus (2016).

65 Typical Member States are Greece and Latvia. See European Commission (2018 b). In practice, as the evaluation of the EC indicates, "Most businesses consider apps, non-embedded software and IoT components to be 'products' pursuant to the Directive". See European Commission (2018a, p. 67).
} 
literature. ${ }^{66}$ On the other hand, uncertainties arise when it comes to the issue of whether relevant digital goods should be categorised as a product or service when they are offered in the service context. There is a huge divergence regarding this issue across the Member States. ${ }^{67}$

Apart from the controversies with regard to the scope of the product, the scope of the producer is also challenged in the context of $3 \mathrm{D}$ printing. According to the law and economics approach, a producer should be subject to strict liability because controlling the producer's activity level can contribute more to reducing product risks. ${ }^{68}$ A designer is excluded from this scope due to his/her remote correlation with the harm. ${ }^{69}$ However, this may be different in the context of 3D printing where the person who works out the CAD file fundamentally determines the ultimate function of the object. In comparison, the person who prints out the object does not play a decisive role since the printing process consists simply in executing the instructions embedded in the CAD file. Therefore, according to the incumbent liability regime, it is unclear whether or not the CAD file maker would be subject to strict liability.

The divergence among EU Member States related to the above-mentioned elements implies an uncertainty at the current stage in terms of deciding whether specific activities within 3D printing are subject to strict liability or to a negligence rule. In other words, the outcome of the assessment could be quite variable across the EU. Moreover, the specific legal situation in particular Member States is not always crystal clear. ${ }^{70}$ Accordingly, the demand for risk shifting may be unpredictable for insurers.

\section{Causal uncertainties}

In addition to the uncertainties that are related to the applicability of liability rules, causal uncertainty is also a factor that increases unpredictability in practice. Under the EPLD, a producer is liable when one of his/her defective products causes damage to an injured party. ${ }^{71}$ Increasingly, as multiple producers might engage in remixing a single product (say within an open-source community such as Model A.1), damage might not be directly linked with a specific party who contributed to it. A joint and several liability mechanism is thus often introduced to deal with the problem of causal uncertainty. ${ }^{72}$ As a result, a producer that engages in production might compensate the injured party proportionately or fully. The specific standard is

\footnotetext{
$\overline{66}$ A typical illustration is given by Howells, Twigg-Flesner and Willett (2017).

67 Most of the Member States (namely 18 in number) insist that damage caused by the service should be solved through a contractual approach. For the Member States that adopt an extra-contractual regime, seven use the fault-based rule and two apply strict liability.

68 Landes and Posner (1985).

69 Article 3 of the EPLD.

70 For instance, in Germany, while specific cases confirmed that online software that is not embedded into material medium could be interpreted as the "product", some verdicts held the opposite standpoint. See Erman/Schiemann $\$ 2$ ProdHaftG.

71 Article 1 of the EPLD.

72 Faure (2016a).
}

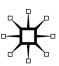


largely different among jurisdictions. ${ }^{73}$ Shifting the risk of causal uncertainty to producers via solidary liability is, however, disliked by insurers. ${ }^{74}$ In this sense, whenever a party is held liable for the damage which is de facto caused by other parties, the party's insurer will take the risk of covering the damage caused by other noninsured actors. $^{75}$

Traditional production is normally based on a linear supply chain through which the role and function of different actors are divided in a relatively clear way. Therefore, even if a producer is required to fully compensate the injured party under the solidary liability rule, there is a good chance they will be able to trace which party also contributed to the damage and to gain reimbursement from this party. In contrast to mass production, a digital design that is used for $3 \mathrm{D}$ printing might be remixed several times before entering the printing procedure. ${ }^{76}$ Unlike traditional production in which different actors can be largely identified and controlled through a linear supply chain, the contributors to the digital design in the context of 3D printing can be situated in different corners of the world. Two further problems with this pattern blur causal certainty. On the one hand, apart from the multiple parties who remix the design, other parties such as the raw material providers, the 3D printer manufacturers and the party who transforms the digital format into the real thing also substantially contribute to the ultimate product. It is technically difficult to establish a causation between damage and a specific party (or parties). On the other hand, even if the damage is correctly linked to a specific designer, it might be very costly to identify the actor and obtain compensation from him/her. Therefore, to establish a certain causation between an act from a specific party and the damage caused in the use of the product is rather difficult in the context of 3D printing. The causal uncertainty might be the result of the increasing unpredictability on the insurer's side, and the insurer might therefore hesitate to be the successor to the risk by providing insurance.

The law and economics with respect to joint injurers normally indicates that, in the absence of insolvency, joint and several liability should not necessarily be a problem. ${ }^{77}$ The injurer who has to compensate the injured party can, in principle, exercise redress against other parties who contributed to the loss in proportion to their contribution. As long as, based on redress, each injurer contributes precisely the amount s/he also added to the risk, efficient incentives for prevention for all contributing actors are provided. However, problems obviously arise in the case of 3D printing where, as indicated, it is often not possible to identify all contributors, let alone to exercise a recourse action against them. The situation could be even worse

\footnotetext{
73 Article 5 of the EPLD provides that where, as a result of the provisions of this Directive, two or more persons are liable for the same damage, they shall be liable jointly and severally, without prejudice to the provisions of national law concerning the rights of contribution or recourse.

74 Abraham (1988) and Katzman (1988).

75 Faure (1995).

76 Remixing an existing digital design is quite common at the current stage, especially on the opensource platforms such as the Thingiverse under Model A.1. Information is available at: https://www.thing iverse.com/explore/popular/.

77 See the basic analysis by Kornhauser and Revesz (1989) and Landes and Posner (1980).
} 
when the cross-border business, which is common in the context of $3 \mathrm{D}$ printing, is taken into consideration. ${ }^{78}$ Therefore, solidary liability may lead to inefficiencies.

To conclude this subsection, a risk might be uninsurable, given that legal rules are unpredictable for insurers, especially when the issue of uncertainties related to the applicable liability rules and causal uncertainty is taken into account by insurers. If we delve into the essential reasons why insurers are reluctant to take a risk and offer insurance, we find that it is difficult for insurers to obtain the information on the development risk caused by the transformative legal regime. If such information can be precisely foreseen and delivered to private actors, the insurmountable problem of arranging insurance will be largely improved. The basic problem potentially leading to a lack of insurance is that in case of so-called insurer ambiguity (when insurers are uncertain concerning particular risks), they may charge a so-called risk premium. ${ }^{79}$ However, when that high uncertainty is not recognised by the demandside, the premiums charged will be judged as excessive by the potential insured and as a result, the supply will not be able to match the demand. That is caused by information asymmetry between the insurer and the insured and thus causes problems in arranging insurance.

\section{Adverse selection and moral hazard}

\section{Problems and remedies}

The previous section has clarified the legal uncertainties that might make risk uninsurable. A risk can also turn out to be uninsurable if insurers do not have enough information on the behaviour of the insured parties. ${ }^{80}$ One problem is adverse selection, which takes place when insurers have difficulty in estimating precisely the risk of each specific party from an ex ante perspective. In this situation, the insurer can determine the premium only at the average level, which further forces the parties with lower risks out of the insurance market while those with higher risks remain. ${ }^{81}$ In this sense, insurers are de facto bearing more risks than expected. Another problem is moral hazard, which refers to a situation from an ex post perspective when insurers find it hard to monitor the activities of the insured parties after offering coverage. An insured party might take fewer precautions. ${ }^{82}$ In order to avoid this, the insurer will take measures to ensure that the insured parties take optimal precautions. ${ }^{83}$ However, this is hard to achieve, since an insurer would have to supervise the insured constantly, and the cost could be extremely high. ${ }^{84}$ To summarise, the presence of adverse selection as well as moral hazard will potentially expose

\footnotetext{
78 Ebrahim (2016).

79 Hogart and Kunreuther (1985) and Kunreuther et al. (1993).

${ }^{80}$ Faure (2016b).

81 Akerlof (1970).

82 See the basic explanation on moral hazard by Arrow $(1963,1968)$.

83 Shavell (1979).

84 Wagner (2009).
} 
insurers to more bad risks than good ones. Different methods are offered in order to reduce adverse selection and moral hazard problems.

The problem of adverse selection can be corrected if the insurer is able to precisely differentiate between the parties with bad risks and those with good risks. ${ }^{85}$ In traditional manufacturing, by requiring a producer to offer specific documents and checking the production condition on the scene, insurers are able to obtain basic information about a particular producer. As the insurer keeps collecting such data, factors such as the scope of production, the certification acquired by the producer as well as others will be taken into account to differentiate risks. As risks are differentiated in detail, the premium can be tailored to different categories, which will to some extent solve the problem caused by adverse selection.

In addition, several ways are offered to remedy the moral hazard problem. One method that is commonly employed by insurers is to offer only partial coverage of the risk. ${ }^{86}$ By doing this, an insured party is partially exposed to the risk, which will incentivise him/her to take some precautions. Another way to deal with moral hazard is to check the activities of the insured parties thoroughly. ${ }^{87}$ In this sense, an insurer is granted the right to investigate the production conditions and ask the insured to report specific items at any time during the existence of the insurance contract. Observations on the insured person's way of working can lead to a higher premium the next time the insured tries to arrange an insurance contract.

Therefore, although the problems of adverse selection and moral hazard cannot be fully solved in the traditional context, insurers are capable of controlling such problems, since private information can be accessed by them in various ways. However, differentiating risks and supervising the activities of those insured could be costly in specific contexts, especially in circumstances where no appropriate instruments are offered to insurers to disclose private information in a credible and costless way. The following subsection will explain why 3D printing does not fit into the traditional way of controlling the adverse selection and moral hazard problems.

\section{Difficulties in the case of 3D printing}

As clarified in the Introduction, when compared to traditional production, 3D printing stands out with its democratised pattern of production, which means that ordinary people are able to take part in production activities regardless of their designing or manufacturing knowledge. Unlike traditional production, in which an insurer can differentiate risks through various instruments, ${ }^{88}$ an insurer can hardly distinguish a bad risk from a good one in the context of 3D printing, since hardly any proper approach can be counted on. ${ }^{89}$ As ordinary people do not need to register at

\footnotetext{
85 Priest (1986).

86 Faure and Hartlief (1998).

87 Faure (1995).

88 Such factors are technical advance, economies of scale, organisational structure and others that could give producers competitive advantages on market.

${ }^{89}$ Heine and Li (2019).
} 
an agency in order to start production, no general information endorsed by a public agency is disclosed to the public. Also, certification is seldom offered to indicate the capacity of specific individual producers according to the variety of the aforementioned business models. ${ }^{90}$ What is more, unlike in the context of conventional production, in 3D printing control mechanisms such as rating systems or standardisation are missing. As 3D printing is typically a new technology, the price mechanism and reputational signalling are also not yet fully available to assist insurers in differentiating risks. As a result, the insurer has little information to differentiate risks. It is notable that even the average level of risk in the context of 3D printing might be difficult to assess. Since the size of the 3D printing market is still increasing rapidly and the scope of the liability regime is to some extent uncertain, an estimation at the moment might only partially reflect the magnitude of harm afterwards. Therefore, in the short run, an insurer that has little information to overcome the problem of adverse selection might hesitate to provide liability insurance. In the long run, however, the insurability problem might improve, provided that clear-cut guidance is offered to diminish the legal uncertainty and that the risk borne by an individual producer can be communicated to the insurer through particular instruments.

Beside the potential insurability problem caused by adverse selection, uncontrollable moral hazard will also deter insurers from offering liability insurance in the context of 3D printing. In contrast with traditional patterns, individual producers applying 3D printing technology are to a large degree decentralised. In other words, anyone who contributes to the designing or manufacturing process, no matter how minor it is, is taking a chance to add value as well as to generate risks. In these circumstances, compared to supervising mass producers, it will be extremely difficult for insurers to check on the activities undertaken by each individual producer. Theoretically, the insurer can make every effort to supervise individual producers at all times. In an extreme case, the insurer can install a camera in an insured's room and employ thousands of people to inspect the behaviour of the insured all the time. However, this can never happen in reality due to the prohibitive expense as well as invasion of the fundamental rights of the insured (e.g. privacy). ${ }^{91}$

Several points can be concluded from the discussion in this section. First, adverse selection and moral hazard problems might be uncontrollable in the context of 3D printing since the democratised production increases the costs of accessing private information for insurers. Second, insurers might in these circumstances have various choices. They could decide not to provide any liability insurance or they could charge a higher risk premium to deal with the adverse selection problem. However, as indicated, that premium may ultimately be too high. The final choice is to provide liability insurance with differentiated premiums, but that is only possible if insurers are able to access information. However, in the latter case, no matter how the

\footnotetext{
90 Currently, only several fabricators under Models B.1 and B.3 show their certified information to consumers.

91 For example, the General Data Protection Regulation (GDPR) set up various fundamental rules relating to the processing of personal data in the EU. According to Article 7 of the GDPR, one important principle is that processing of personal data is based on the consent of the data subject.
} 
information is accessed, there is a danger that the marginal cost of accessing information might outweigh the marginal benefits. The key implication of this analysis is that proper instruments should be designed in the context of 3D printing to enable insurers to access the private information of those insured parties in a costless and credible way.

\section{Capacity}

The magnitude of the damage also plays a role in insurability. If the magnitude of the damage is extremely large, it could even exceed the capacity of an insurer so that the insurer might decide not to cover such a risk. Uninsurability issues caused by large-scale damage are normally observed in catastrophe risk and sometimes in a traditional production context. It is not immediately clear whether the small individual producers potentially engaged in 3D printing could also create large-scale damage. Currently, it may be reasonable to assume that product risk generated through the application of 3D printing would normally be relatively limited in scale. As 3D printing is still such a new technology, there is not yet any convincing empirical evidence. However, if the assumption is correct that the damage resulting from $3 \mathrm{D}$ printing should not necessarily be large, capacity would not be the major worry for insurers. ${ }^{92}$ To conclude, in this section we argued that risk can be less predictable in the context of 3D printing. The existing legal uncertainties as well as the increasing information asymmetries may render insurers less willing to provide coverage. Traditionally, a variety of measures are adopted by insurers to deal with the risks that are less predictable; for example, insurers could develop various underwriting techniques to screen in advance for good loss control. What is more, insurers apply experience rating through which people with bad risk are charged a higher premium. Moreover, insurers could only offer partial coverage, as a result of which the insured parties would be expected to take some precautions. One question here is the extent to which these conventional measures will still play a role in the context of $3 \mathrm{D}$ printing. In addition, a more interesting question here is whether new solutions could be employed to tackle the uninsurability problem. The next section will therefore look more closely at exploring these issues.

\section{Potential solutions to the uninsurability problem}

So far, this article has clarified the extent to which production activities are disrupted by $3 \mathrm{D}$ printing compared to the traditional ways of production, the extent to which new actors might generate product risks and the extent to which insurability turns out to be a controversial issue. In summary, insurers' access to private and public information in a costless and credible way will be of great importance in dealing with insurability problems in the context of 3D printing. This section will

\footnotetext{
92 It should be noted that the issue of capacity might be a concern for insurers as new printing methods with new capacities are being developed.
} 
advance several approaches that might improve the accessibility of information to tackle the uninsurability issue.

\section{Using legal instruments to increase legal certainty}

As we have discussed before, legal uncertainties may increase the unpredictability of the risk. In order to reduce legal uncertainties, several measures can be taken in the context of 3D printing.

First and foremost, it is necessary to clarify the exact kind of liability rules that apply to the damage resulting from 3D printing. It is of great importance to figure out whether non-embedded digital goods and the goods bundled with a service fall into the scope of what is legally considered a "product". As discussed previously, different Member States have quite different attitudes to such issues at the moment. While the European Commission is conducting many studies and evaluations to figure out these issues, it is not yet known whether further harmonisation will take place. ${ }^{93}$ Therefore, it is reasonable to conclude here that the divergence and disputes pertaining to the definition of elements such as "producer" and "product" will continue. In fact, the answer to this question should be carefully evaluated from a theoretical perspective. Distinguishing whether the goods mentioned above are literally categorised as a product or not makes no sense, since the criteria which are based on physical/digital and product/service dichotomy could be blurred by the constantly developing technologies. Instead, more reliable criteria could be developed by evaluating whether the activities of relevant parties are risky and whether a party holds more information to reduce the product risk. If the answer is yes, then non-embedded goods as well as goods in a bundle with a service should be considered as a product. From this dimension, more concrete analyses are expected in the near future to define the scope of liability.

Second, predictability is expected to improve by clarifying the extent to which individual producers are subject to strict liability. Currently, the clarification of this issue is impinged upon by case law. Unlike traditional production in which occasional producers and normal producers respectively are subject to negligence and strict liability, individual producers in the context of 3D printing appear to be situated somewhere in between. While some individual producers might be more like occasional producers, others are more like normal producers. Therefore, concrete criteria are necessary to examine the scope of liability for an individual producer in each specific case. ${ }^{94}$ The scale of production, the use of the product, the price of the product and their effect as well as other factors might be clarified by authorities to help courts make a decision.

In the past decades, the world has witnessed increasing human competence in production and an expanding scope of product liability where new value has been added. In contrast to the rapid development of disruptive technology, the technique

93 European Commission (2018a, b).

94 Berkowitz (2014). 
used for risk shifting seems to have stagnated. Therefore, there is a pressing need for insurers to adopt advanced methods that are able to differentiate risks and monitor those insured in a costless way.

\section{Risk differentiation and monitoring insured parties}

As we have discussed in the previous section, insurability might turn out to be a problem in the context of 3D printing because it could be costly for insurers to differentiate risks and monitor the insured unless an efficient instrument can be accessed by insurers to narrow down the information asymmetry. If no method is offered to tackle this problem, social welfare will be diminished since risk-averse parties will have to bear the risk. ${ }^{95}$ If this is the case, actors will be deterred from taking up activities that could have generated more benefits. Therefore, proper measures to enhance risk differentiation and improve monitoring problems are required in the context of 3D printing. In this way, adverse selection and moral hazard will be reduced and insurability of the risk will be further improved.

The remainder of this section aims at discussing potential solutions to tackle the adverse selection and moral hazard problems in the context of 3D printing. We will first examine this problem using traditional methods and then delve into potential new methods, which are platform governance and insurance technology.

\section{Policy conditions under the insurance contract}

The conventional way to tackle adverse selection and moral hazard is via risk differentiation in the insurance contract. In this sense, insurers can always ask the insured to report specific items to reduce information asymmetries. For example, before making a decision an insurer can ask an insured party to report personal information by filling in an inventory in which the insured will be required to offer a variety of information such as the type of 3D printing used for production, the source of designs or the software used for making the digital design, the educational background, the function and potential use of printed products, the channel and the scale of distribution, etc. The list could be prolonged endlessly whenever an item is linked with the product risks. By doing so, the insurer will have some indication of the risk ex ante and can modify this inventory ex post. However, additional problems will be incurred using this model in the context of 3D printing.

First, drafting such a long list largely depends on the capacity of a specific insurer. In this sense, it not only requires an insurer to have a thorough understanding of the risk borne for each customised production ex ante but also to be able to collect a great deal of portfolios so as to be able to differentiate risks properly. Second, the detailed inventory may restrict the defence of the insurer. In the absence of the questionnaire it will be the burden of the policyholder rather than the insurer to

${ }^{95}$ Shavell (1987). 
report the cases affecting the insured risk. Third, risk differentiation and checking on those who wish to be insured can, under insurance conditions, be costly in the context of 3D printing. As the premium of each case is normally minor, the marginal cost of differentiating risk as well as checking up on each insured might outweigh the benefit. If this is the case, liability insurance would not be offered. Therefore, in a context where production is decentralised to individuals, instruments are needed to better differentiate risks and monitor the insureds.

\section{Platform governance}

The previous analysis of the various business models has shown that platforms play a crucial role in matching supplies and demands in the context of $3 \mathrm{D}$ printing. ${ }^{96}$ In practice, the role of platforms is different in various business models.

Under models A.1, A.2 and B.3, a platform serves as a community or a marketplace so that supplies and demands can match with each other on their own efforts without the intervention of the platform. In these cases, while the platform does not take an active role in stimulating transactions, it does to some extent improve risk differentiation. One example is the adoption of a rating system that allows a person who downloads a digital file to share first-hand information on its potential risk. ${ }^{97}$ In addition, a platform can differentiate the potential risk of a product through a thorough categorisation system ${ }^{98}$ as well as a filtering system. ${ }^{99}$

In recent years, the importance of platform governance has been increasingly appreciated by stakeholders. Some operators are motivated to improve the governance of platforms for the purpose of gaining more profits. For example, a shift from Model B.2 to Model B.3 has already been exercised by "3D Hubs". ${ }^{100}$ With the adoption of the new business model, it is the "3D Hubs" that serves as an intermediary to choose the qualified printing service for its customers. Within this business model, only the fabricator with a certificate of an ISO standard is qualified to build a partnership with "3D Hubs". Therefore, fabricators with lower risks are differentiated from the ones with higher risks through a transformation of the business model.

It is noteworthy that relying on platform governance to differentiate risks and checking up on the insureds will also generate some problems. For instance, the variables included in the algorithm may be biased. ${ }^{101}$ If this is the case, specific individual producers might be discriminated against and forced out of the market unfairly.

\footnotetext{
96 Lobel (2018).

97 Tadelis (2016).

98 Categorisation means that a platform can divide the CAD files and printing service into different groups through which the function of relevant goods can be disclosed. For example, under Thingiverse, all the CAD files that are exhibited online are categorised into ten groups.

99 A filtering system is controlled by specific algorithms. In this system, a CAD file or a 3D printer is shown to a consumer with the preference set by the platform. Normally, the performance of a filtering system is closely linked with the algorithm developed by the platform.

100 For detailed information on the transformation of the business model within 3D Hubs, see: https:// www.3dhubs.com/blog/3d-hubs-announces-suite-of-new-features-and-switch-to-fulfilled-by-3d-hubs2/https://www.3dhubs.com/blog/3d-hubs-announces-suite-of-new-features-and-switch-to-fulfilled-by3d-hubs-2/.

101 Kroll et al. (2016) and Kleinberg et al. (2019).
} 
Also, platform governance is by its very nature driven by private interest. Hence there is speculation as to how to motivate platforms to include the public interest concern into their business.

\section{InsurTechs}

Traditionally, the adverse selection and moral hazard problems arise because an insurer has insufficient information or no capacity to evaluate the information acquired from the insured parties. In this sense, when we talk about differentiating and monitoring risk, we are talking about how the information of insured parties could be accessed by insurers in a costless and credible way. In recent years, emerging technologies promise a new way in terms of differentiating and monitoring risk. ${ }^{102}$ The potential capacities of some typical technologies are:

- Sensors and Internet of things (IoT) that are able to excavate the exploding amount of information ${ }^{103}$;

- Data analytics that can increase the predictability of this information by differentiating between the various collected risks ${ }^{104}$;

- Smart contracts that can promote the execution of the policy conditions ${ }^{105}$;

In addition to the above-mentioned technologies, one promising InsurTech that is expected to have a substantial impact on narrowing information asymmetry in the context of 3D printing is the so-called blockchain technology. Blockchain technology is essentially a database that is used for storing and updating information. ${ }^{106}$ Unlike the traditional method whereby information is stored and updated by a central ledger (e.g. insurer), every player in the blockchain serves as a node that can store the whole information of a blockchain. In other words, whenever a player within the blockchain changes or updates information, all the other actors throughout the whole network are informed immediately. It is also noteworthy that once such information is updated to all the members on the network, it is impossible to withdraw this action. What is more, such information is traceable. ${ }^{107}$

The technological characteristics of blockchain have wide implications for information asymmetry and credit problems. In the traditional context, credit is determined by a central agent (e.g. the insurer). The extent to which such an agent could correctly understand a kind of risk is thereby largely dependent on the capacity to access all the relevant information. In this sense, a central agent may misunderstand risk and consequently make a bad decision. In contrast to the conventional picture, with the application of blockchain, information is no longer censored by

\footnotetext{
102 Van den Berghe (1998), Schanz and Sommerrock (2016), OECD (2017) and Cappiello (2018).

103 Swan (2012).

104 Helveston (2016).

105 Raskin (2017).

106 McKinsey (2016).

107 Deloitee (2016).
} 
a central agent. Instead, any private information is stored and updated across the whole network. It is therefore impossible for an actor to conceal the relevant information unless it is agreed by at least half of the members, which is highly unlikely. Therefore, blockchain technology has the potential to solve the information asymmetry problem. Further, it promises a reconstruction of the credit system, since it indicates that a credit system can be well established without the monitoring of a central agent. The more actors involved in the network, the more stable and credible the system will be. It can thus be expected that blockchain technology will be compatible with a decentralised context like 3D printing.

In the context of 3D printing, the application of blockchain technology also has huge implications for the issue of risk differentiation, considering that a wide range of information on insured parties can be accessed by an insurer before concluding an insurance contract. Provided that the platform embeds blockchain technology within its architecture, then all the individual actors all over the world who established their business on this specific platform would be included within this framework. If this is the case, all the activities relating to a specific party could be recorded on the network irreversibly. In particular, the application of blockchain technology not only fosters ex ante risk differentiation but also enables the behaviour of CAD file makers and fabricators to be monitored from an ex post perspective. By adopting blockchain technology, information that cannot easily be observed in a traditional context is expected to be disclosed in a credible way. The typical recorded safety information is:

- How many CAD files have been designed or remixed by a CAD file maker

- How many final objects have been manufactured by a fabricator

- What these CAD files and products are used for

- Whether some of these CAD files or products have been reported as dangerous

- In which countries the CAD files of a particular party were downloaded

Such information can not only help the platform to better understand the heterogeneity of its members but also serve as an objective source to insurers. First, the problem of adverse selection could be alleviated since insurers can rely on credible information to narrow the risk pool. Second, the insured parties are expected to behave appropriately because the risk caused by their activities can be swiftly detected by the insurers, who may update the provisions in line with the actual level of risk. In short, by embedding blockchain technology into the platform, technologies instead of people or entities will take on the role of detecting information. Disclosing information in this way not only provides relevant governors (e.g. the platform and insurer) with a better capacity to assess the risk posed by CAD file makers and fabricators in a decentralised environment but also serves as an incentive to remind these parties that they should behave appropriately. Thus blockchain is expected to be the technology that can promote deterrence and risk shifting.

Obviously, the potential of blockchain technology has not been fully discovered to date in the sector of insurance. ${ }^{108}$ However, as blockchain technologies continue

108 Gilbert (2016). 
to develop, the value they could add to the insurance sector would massively exceed their cost. As a result, it is estimated that the insurance industry will swiftly embrace blockchain technology within the next few years. ${ }^{109}$.

However, it should be noted that the performance of blockchain technology in the insurance industry is constrained by many other concerns. First, the performance of blockchain technology essentially depends on the development of other key technologies such as data analytics and smart contracts. The second issue concerns the regulatory perspective. In this sense, the advantage brought about by InsurTechs is by no means exclusive to insurers. New parties (e.g., InsurTech start-ups and online platforms) that develop or have access to InsurTechs may also apply for a licence and step into the insurance industry. This transformation generates further issues relating to the regulation on competition, privacy and security. ${ }^{110}$ Moreover, challenges concerning the extent to which InsurTechs can appropriately fit into the current business models in the context of 3D printing is not yet clear. Additional costs may deter stakeholders from adopting relevant InsurTechs. ${ }^{111}$ Therefore, more exploration is encouraged to detect in practice the appropriate applicable scenarios for combining the InsurTechs and insurance industries. ${ }^{112}$ Beyond that, to increase legal certainty, we should also pay attention to the establishment of a regulatory regime for blockchain.

\section{Concluding remarks}

The wide application of $3 \mathrm{D}$ printing adds huge value to the sector of production by breaking down the constraint of scale economies and satisfying the customised demands on the "long tail". However, at the same time, this trend poses risks inherent in different business models. The current liability regime across the EU manifests divergent opinions on the issue of which party should be chosen to undertake the liability and bear the risk generated in the context of 3D printing. This article has focused on the risk shifting problem rather than discussing the performance of liability rules. We showed that while imposing strict liability on digital designers and fabrication service providers may provide a better deterrence effect, the risk bearers are meanwhile confronted with increasing risk-shifting problems, since risk becomes unpredictable and thereby uninsurable in the context of 3D printing. This article reveals that uninsurability not only stems from legal uncertainties but also from the increasing adverse selection and moral hazard problems. As a consequence, insurers turn out to be hesitant in providing liability insurance to liability bearers in the context of $3 \mathrm{D}$ printing.

\footnotetext{
109 McKinsey (2016)

110 Peppet (2014) and Mehra (2015).

111 Sklaroff (2017).

112 Valentina et al. (2018).
} 
Several methods are proposed in this article to improve insurability in the context of $3 \mathrm{D}$ printing. On the one hand, the appropriate allocation of liability per se still plays an essential role in improving insurability. In order to eliminate legal uncertainties, further research must be conducted to carefully determine whether and to what extent the specific parties (e.g. CAD file makers and fabricating service providers) are subject to strict liability or to other rules. By doing so, insurers will have a better estimation of the demand of liability insurance in general. On the other hand, new approaches can be embraced by insurers to reduce the adverse selection and moral hazard in evaluating the risk pertaining to a specific party. We find that the improvement of platform governance and the adoption of InsurTechs promise a bright future for risk assessment in the digital age. Especially with the adoption of blockchain technology, insurers are expected to precisely evaluate the scale of risk and monitor the behaviour of insured parties in a credible and costless way.

Acknowledgements This paper was presented in the 18th Joint Seminar of the European Association of Law and Economics and the Geneva Association. The authors would like to thank Pierpaolo Marano, the organisers and participants of the Joint Seminar, as well as the editors and two anonymous reviewers for their helpful comments.

\section{References}

Abraham, K.S. 1988. Environmental liability and the limits of insurance. Columbia Law Review 88: 942-988.

Ackel, A.E. 2018. Extending liability to micro-manufacturers of the future: Applying the CASUAL seller exception in the context of 3-D printing. UC Irvine Law Review 8: 121.

Akerlof, G. 1970. The market for lemons: Quality uncertainty and the market mechanism. The Quarterly Journal of Economics 84 (3): 488-500.

Anderson, C. 2007. The long tail: How endless choice is creating unlimited demand. London: Random House.

Arlen, J. 2010. Contracting over liability: Medical malpractice and the cost of choice. University of Pennsylvania Law Review 158: 957-1023.

Arrow, K. 1968. The economics of moral hazard: Further comment. American Economic Review 58: 537-539.

Arrow, K. 1963. Uncertainty and the welfare economics of medical care. American Economic Review 53: 941-973.

Baker, T. 2004. Insuring liability risks. The Geneva Papers on Risk and Insurance-Issues and Practice 29 (1): 128-149.

Beck, J.M., and M.D. Jacobson. 2017. 3D printing: What could happen to products liability when users (and everyone else in between) become manufacturers. Minnesota Journal of Law, Science \& Technology 18: 143.

Berkowitz, N.D. 2014. Strict liability for individuals-the impact of 3-D printing on products liability law. Washington University Law Review 92 (4): 1019.

Berman, B. 2012. 3-D printing: The new industrial revolution. Business Horizons 55 (2): 155-162.

Bogers, M., R. Hadar, and A. Bilberg. 2016. Additive manufacturing for consumer-centric business models: Implications for supply chains in consumer goods manufacturing. Technological Forecasting and Social Change 102: 225-239.

Calabresi, G. 1970. The costs of accidents: A legal and economic analysis. New Haven, CT: Yale University Press.

Cappiello, A. 2018. Technology and the insurance industry: Re-configuring the competitive landscape. New York: Springer.

Coase, R.H. 1960. The problem of social cost. The Journal of Law \& Economics 3: 1-44. 
Daughety, A.F., and J.F. Reinganum. 2013. Economic analysis of products liability: Theory. In Research handbook on the economics of torts, ed. J.H. Arlen, 69-96. Cheltenham: Edward Elgar.

Dean, B. 2018. An exploration of strict products liability and the internet of things. Available at SSRN: https://ssrn.com/abstract=3193049. March 13.

Deloitee. 2016. What is Blockchain. Available at:https://www2.deloitte.com/content/dam/Deloitte/uk/ Documents/Innovation/deloitte-uk-what-is-blockchain-2016.pdf.

Diamond, P.A. 1974. Single activity accidents. The Journal of Legal Studies 3 (1): 107-164.

Ebrahim, T.Y. 2016. 3D Printing: Digital Infringement \& Digital Regulation. Northwestern Journal of Technology and Intellectual Property 14: 37.

Eling, M., and M. Lehmann. 2018. The impact of digitalization on the insurance value chain and the insurability of risks. The Geneva Papers on Risk and Insurance-Issues and Practice 43 (3): 359-396.

Engstrom, N.F. 2013. 3-D printing and product liability: Identifying the obstacles. University of Pennsylvania Law Review Online 162: 35.

Epstein, R.A. 1980. Modern products liability law. Westport: Quorum Books.

European Commission. 2018a. Evaluation of Council Directive 85/374/EEC of 25 July 1985 on the approximation of the laws, regulations and administrative provisions of the Member States concerning liability for defective products. SWD(2018) 157 final, Available at: https:/eur-lex.europa.eu/ legal-content/EN/TXT/PDF/?uri=CELEX:52018SC0157\&from=EN.

European Commission. 2018b. Evaluation of Council Directive 85/374/EEC on the approximation of laws, regulations and administrative provisions of the Member States concerning liability for defective products. Available at: https://publications.europa.eu/en/publication-detail/-/publication/d4e3e 1f5-526c-11e8-be1d-01aa75ed71a1/language-en.

Faure, M. G. 2004. Alternative compensation mechanisms as remedies for uninsurability of liability. The Geneva Papers on Risk and Insurance-Issues and Practice 29(3), 455-489.

Faure, M., and T. Hartlief. 1998. Remedies for expanding liability. Oxford Journal of Legal Studies 18 (4): 681-706.

Faure, M., and T. Hartlief. 2003. Insurance and expanding systemic risks. Paris: OECD.

Faure, M.G. 1995. The limits to insurability from a law and economics perspective. The Geneva Papers on Risk and Insurance-Issues and Practice 20 (4): 454-462.

Faure, M.G. 2016a. Attribution of liability: An economic analysis of various cases. Chicago-Kent Law Review 91 (2): 603-635.

Faure, M.G. 2016b. Economic analysis of product liability. In European product liability: An analysis of the state of the art in the era of new technologies, ed. P. Machnikowski, 619-665. Cambridge: Principles of European Tort Law.

Geistfeld, M. 1988. Imperfect information, the pricing mechanism, and products liability. Columbia Law Review 88 (5): 1057-1072.

Geistfeld, M.A. 2009. Products liability. In Tort law and economics, ed. M. Faure, 287-340. Cheltenham: Edward Elgar.

Geistfeld, M.A. 2010. Legal ambiguity, liability insurance, and tort reform. DePaul LawReview 60: 539.

Gerner, J.L., and W.K. Bryant. 1981. Appliance warranties as a market signal? Journal of Consumer Affairs 15 (1): 75-86.

Giarini, O. 1995. Insurability and the Economic Relevance of Insurance: A Historical Economic Perspective. The Geneva Papers on Risk and Insurance - Issues and Practice 20 (4): 419-422.

Gibson, I., D. Rosen, and B. Stucker. 2015. Additive manufacturing technologies-3D printing, rapid prototyping, and direct digital manufacturing. New York: Springer.

Gilbert, S. 2016. The Hype cycle of insurance disruption. Available at: https://www.insurancetimes. co.uk/innovation-blog-the-hype-cycle-of-insurance-disruption/1417196.article.

Goldberg, V. 1974. The economics of product safety and perfect information. The Bell Journal of Economics and Management Science 5 (2): 683-688.

Grossman, S.J. 1981. The informational role of warranties and private disclosure about product quality. The Journal of Law and Economics 24 (3): 461-483.

Hamilton, N. 1995. Insurability: Threats and opportunities. The Geneva Papers on Risk and Insurance-Issues and Practice 20 (4): 414-418.

Heine, K., and S. Li. 2019. What shall we do with the drunken sailor? Product safety in the aftermath of 3D printing. European Journal of Risk Regulation 10 (1): 23-40.

Helveston, M.N. 2016. Consumer protection in the age of big data. Washington University Law Review 93 (4): 859. 
Hogart, R.M., and H. Kunreuther. 1985. Ambiguity and insurance decisions. The American Economic Review 75 (2): 386-390.

Howells, G., C. Twigg-Flesner, and C. Willett. 2017. Product liability and digital products. In $E U$ internet law, ed. A. Savin, 183-195. Cham: Springer.

Hylton, K.N. 2012. The law and economics of products liability. Notre Dame Law Review 88: 2457.

Karten, W.T. 1997. How to expand the limits of insurability. The Geneva Papers on Risk and Insurance-Issues and Practice 22 (4): 515-522.

Katzman, M.T. 1988. Pollution liability insurance and catastrophic environmental risk. The Journal of Risk and Insurance 55 (1): 75-100.

Khorram Niaki, M., and F. Nonino. 2017. Impact of additive manufacturing on business competitiveness: A multiple case stud. Journal of Manufacturing Technology Management 28 (1): 56-74.

Kleinberg, J., J. Ludwig, S. Mullainathan, and C.R. Sunstein. 2019. Discrimination in the age of algorithms. National Bureau of Economic Research (Working No. 25548).

Kornhauser, L.A., and R.L. Revesz. 1989. Sharing damages among multiple tortfeasors. The Yale Law Journal 98 (5): 831-884.

Kousky, C., and R. Cooke. 2012. Explaining the failure to insure catastrophic risks. The Geneva Papers on Risk and Insurance-Issues and Practice 37 (2): 206-227.

Kroll, J., J. Huey, S. Barocas, E.W. Felten, J.R. Reidenberg, D.G. Robinson, and H. Yu. 2016. Accountable algorithms. University of Pennsylvania Law Review 165: 633.

Kunreuther, H., R. Hogart, and J. Meszaros. 1993. Insurer ambiguity and market failure. Journal of Risk and Uncertainty 7 (1): 71-87.

Landes, W.M., and R.A. Posner. 1980. Joint and multiple injurers: An economic analysis. The Journal of Legal Studies 9 (3): 517-524.

Landes, W.M., and R.A. Posner. 1985. A positive economic analysis of products liability. The Journal of Legal Studies 14 (3): 535-567.

Landes, W.M., and R.A. Posner. 1987. The economic structure of tort law. Cambridge: Havard University Press.

Lobel, O. 2018. Coase and the platform economy. In The Cambridge handbook of the law of the sharing economy, ed. N.M. Davidson, M. Finck, and J.J. Infranca, 67-77. Cambridge: Cambridge University Press.

Machnikowski, P. 2016. European product liability: An analysis of the state of the art in the era of new technologies. Cambridge: Intersentia.

Magnus, U. 2016. Product liability in Germany. In European product liability, ed. P. Machnikowski, 237-274. Cambridge: Intersentia.

McKean, R.N. 1970. Products liability: Implications of some changing property rights. The Quarterly Journal of Economics 84 (4): 611-626.

McKinsey \& Company. 2016. Blockchain in insurance: opportunity or threat? Available at: https:// www.mckinsey.com/ /media/McKinsey/Industries/Financial\%20Services/Our\%20Insights/Block chain $\% 20$ in $\% 20$ insurance $\% 20$ opportunity $\% 20$ or $\% 20$ threat/Blockchain-in-insurance-opportunit y-or-threat.ashx.

Mehl, C. 1998. Insurability of risks on the information highway, from the user's point of view. The Geneva Papers on Risk and Insurance-Issues and Practice 23 (1): 103-111.

Mehra, S.K. 2015. Antitrust and the robo-seller: Competition in the time of algorithms. Minnesota Law Review 100: 1323.

OECD. 2017. Technology and innovation in the insurance sector.

Oi, W.Y. 1973. The economics of product safety. The Bell Journal of Economics and Management Science 4 (1): 3-28.

Parisi, F. 2004. The harmonization of legal warranties in European sales law: An economic analysis. American Journal of Comparative Law 52: 403.

Peppet, S.R. 2014. Regulating the Internet of Things: First steps toward managing discrimination, privacy, security and consent. Texas Law Review 93: 85.

Priest, G.L. 1986. The current insurance crisis and modern tort law. Yale Law Review 96: 1521.

Raskin, M.T. 2017. The law and legality of smart contracts. Georgetown Technology Law Review 1: 305-341.

Rayna, T., and L. Striukova. 2014. The impact of 3D printing technologies on business model innovation. In Digital enterprise design \& management, ed. P.-J. Benghozi, D. Krob, A. Lonjon, and H. Panetto, 119-132. New York: Springer. 
Redwood, B., F. Schöffer, and B. Garret. 2017. The 3D printing handbook: Technologies, design and applications. Amsterdam: 3D HUBS.

Schäfer, H.B., and F. Müller-Langer. 2009. Strict liability versus negligence. In Tort law and economics, ed. M. Faure, 3-45. Cheltenham: Edward Elgar.

Schanz, K.U., and F. Sommerrock. 2016. Harnessing technology to narrow the insurance protection gap. Zurich: The Geneva Association.

Shavell, S. 1979. On moral hazard and insurance. The Quarterly Journal of Economics 93 (4): $541-562$.

Shavell, S. 1980. Strict liability versus negligence. The Journal of Legal Studies 9 (1): 1-25.

Shavell, S. 1982. On liability and insurance. Bell Journal of Economics 13 (1): 120-132.

Shavell, S. 1987. Economic analysis of accident law. Cambridge: Harvard University Press.

Sklaroff, J.M. 2017. Smart contracts and the cost of inflexibility. University of Pennsylvania Law Review 166: 263.

Skogh, G. 1998. Development risks, strict liability, and the insurability of industrial hazards. The Geneva Papers on Risk and Insurance-Issues and Practice 23 (2): 247-264.

Spence, M. 1977. Consumer misperceptions, product failure and producer liability. The Review of Economic Studies 44 (3): 561-572.

Staed, K.C. 2017. Open source download mishaps and product liability: Who is to blame and what are the remedies. Saint Louis University Public Law Review 36: 169.

Swan, M. 2012. Sensor mania! The internet of things, wearable computing, objective metrics, and the quantified self 2.0. Journal of Sensor and Actuator networks 1 (3): 217-253.

Tadelis, S. 2016. Reputation and feedback systems in online platform markets. Annual Review of Economics 8: 321-340.

Ulrich, M. 2016. Product liability in Germany. In European product liability: An analysis of the state of the art in the era of new technologies, ed. P. Machnikowski, 237-274. Cambridge: Intersentia.

Valentina, G., F. Lamberti, C. Demartini, and C. Pranteda. 2018. Blockchain and smart contract for insurance: is the technology mature enough? Future Internet 10 (2): 20.

Van den Berghe, L. 1998. Shaping the future for the insurance sector. The Geneva Papers on Risk and Insurance-Issues and Practice 23 (4): 506-518.

Vermaat, A.J. 1995. Uninsurability: A growing problem. The Geneva papers on risk and insurance: Issues and Practice 20 (4): 446-453.

Wagner, G. 2009. Tort law and liability insurance. In Tort law and economics, ed. M. Faure, 377-405. Cheltenham: Edward Elgar Publishing.

Publisher's Note Springer Nature remains neutral with regard to jurisdictional claims in published maps and institutional affiliations.

\section{About the authors}

Michael Faure is professor of Comparative and International Environmental Law at Maastricht University. He is also professor of Private Law and Economics at the Institute of Law and Economics at Erasmus University Rotterdam.

Shu $\mathrm{Li}$ is $\mathrm{PhD}$ candidate at the Institute of Law and Economics at Erasmus University Rotterdam. He is also a visiting researcher at the Department of Economics at the University of Bologna. 